\title{
EFFECTS ON BIG GAME OF HARVESTING CONIFEROUS FORESTS IN WESTERN ALBERTA
}

\author{
By JOHN G. STELFOX ${ }^{1}$
}

John G. Stelfox has been employed during the past $51 / 2$ years with Fish and Wildlife Division, Department of Lands \& Forests, Edmonton, Alberta. He has been working chiefly on big game in the north west part of Alberta. Mr. Stelfox has a Bachelor of Science degree in Agriculture from the University of Alberta and is working toward a Master's degree at Utah State University. He worked for three summers on cereal and forage crop experimental studies in the Yukon under the Federal Dept. of Agriculture.

\section{$A B S T R A C T$}

Big game populations and range conditions were studied in a mature white spruce forest prior to logging and for the first 5 years following logging. Cutting was on a clear-cut basis with strips cut 5 and 10 chains wide and $40-48$ chains long with intervening residual strips left 5 chains wide. Cutover areas scarified with a D-9 "Cat" equipped with 3 rakers mounted to the lower blade edge were compared to unscarified areas. Information was gathered on plant species, numbers, utilization, canopy coverage, browse forage yields and heights, and seasonal numbers and distribution of big game.

In general, scarification following logging retarded big game forage production and utilization one to two years compared to the unscarified logged areas. Usable browse production dropped from $529 \mathrm{lbs}$. per acre under mature spruce to $101 \mathrm{lbs}$. in the scarified and $187 \mathrm{lbs}$. in the unscarified areas. Although the browse canopy coverage was greater in the mature forest than in the logged areas five years following logging, the weight of usable browse, and the actual summer utilization of the available browse, were substantially greater in the logged areas. Grass encroached quickly on the cut over strips until in 5 years it covered approximately 50\% of the ground in both the scarified and unscarified areas. This dense grass coverage appeared to impede coniferous seed germination and survival. Five years after logging, forb coverage had tripled in scarified areas and increased four-fold in the unscarified strips, over that present in the uncut spruce. Deer and elk used these forbs as their chief summer food in the cut over strips.

During the first 5 years, big game use of cut over areas was confined almost entirely to the summer. Deer were not frightened out of the areas being logged, as were the elk and moose, and utilized the cut over areas much more extensively.

\section{INTRODUCTION}

In 1955 the first pulp-mill was erected in Alberta. The original lease area consisted of 3,000 square miles of white and black spruce (Picea glauca and $P$. mariana), lodgepole pine (Pinus contorta), aspen (Populus tremuloides), and balsam poplar (Populus balsamifera). The foothills region of western

\footnotetext{
${ }^{1}$ Fish \& Wildlife Division, Edmonton, Alberta.
} 
Alberta where most of Alberta's coniferous timber is produced supports much of Alberta's big game population. This includes moose (Alces americana), elk (Cervus canadensis), mule deer (Odocoileus hemionus), white-tailed deer (Odocoileus virginianus), woodland caribou (Rangifer tarandus), grizzly bear (Ursus horribilis), and black bear (Eurarctos americanus).

This study was designed to determine the effects of various logging and post-logging treatments on big game range in the foothills region. Permanent range plots were established in the three common forest types, viz. white spruce, lodgepole pine, and a mixture of spruce, pine and poplar characteristic of the river valley systems. Within each forest type plots were established in mature timber as well as in a logged over and scarified area. Big game exclosure plots were established in one cut over scarified strip for each of the three forest types.

This paper deals only with the data obtained thus far for the white spruce forest. At present mature coniferous forests in Alberta are not conducive to large big game populations (except perhaps on elk and caribou winter range) due to the shortage of palatable shrubs, forbs and grasses. Marked changes in big game numbers are expected following the removal of the spruce and pine canopy when the brush seral stage becomes well established.

The study deals with plant species, plant numbers, canopy coverage, browse forage yields and heights, utilization, seasonal big game abundance in a mature white spruce forest and during the first five years following logging. Logged over areas that have been scarified are compared to unscarified areas. From a wildlife management standpoint, a study of the influence of various silvicultural practices on big game range carrying capacity is helpful: (1) in forecasting future big game populations and range carrying capacities in virgin timber stands open to logging, and (2) in placing relative values on the various logging and post-logging techniques in regard to big game production. These values could be used in properly assessing the merits of implementing various logging practices on valuable big game range.

Of major concern to commercial forest interests logging at northern latitudes has been the slow recovery of conifers following logging. A major contributing factor to the slow return of conifers appears to be the poor survival rate of spruce and pine seedlings germinating on the cold, mossy, boreal forest floor. Most seedlings perish before penetrating the thick mossy cover to the soil below. One stepped-up forest regeneration practice employed by the pulp company at Hinton consists of scarifying newly logged-off areas with a D-9 "Cat" equipped with three rakers attached to the lower edge of the blade. These rakers mix the moss layer with the soil, producing a warmer, more nutritious and firmer medium in which seedlings can root. Tests to date have revealed good germination and survival of coniferous seedlings following scarification wherever coniferous seed was present. Studies by the author and Dr. R. G. H. Cormack of the University of Alberta in 1957 showed 700 spruce seedlings per acre and 1,113 pine seedlings per acre in separate logged over spruce and pine forests one year following scarification. In the same locality where no scarification was employed, no seedlings were found. 


\section{Study Area AND Methods}

The area selected for study is located near Hinton, Alberta, at latitude $53^{\circ} 20^{\prime}$ and longitude $117^{\circ} 54^{\prime}$. The nearly solid stand of mature white spruce forest averaged 125-140 years of age. The white spruce association resembled closely the shrub-herb faciation described by Moss (1953). The stage of association development compared to stage 4 of coniferous forest succession described by Cormack (1953) except that fir was absent in the association. Small amounts of poplar and willow (Salix spp.) mainly along water courses and areas of "blow-down" interrupted the otherwise dense spruce forest.

An estimate of the big game population immediately prior to logging activities in 1956 was 2.0 deer, 1.5 moose, 1.0 elk, 0.25 black bear, and 0.10 grizzly bear per square mile. The area served as summer and winter range though a slight seasonal movement to and from the adjacent mountains and foothills may have occurred. Movement of elk and bear between the study area and the adjacent National Park was known to occur.

The annual precipitation at Entrance about five miles northeast of the study area averaged 22.59 inches from 1955-1960. Rainfall accounted for 16.13 inches and snowfall for 6.46 inches. The average monthly winter snowfall is presented in Table 1.

Average mean monthly temperature readings for the three-year period 1957-1960 at Hinton are presented in Table 2.

The soil, mainly of a loess nature, contained 75 pounds of $\mathrm{NO}_{3}, 2.3$ pounds of $\mathrm{P}_{2} \mathrm{O}_{i}$, and 70 pounds of $\mathrm{K}_{2} \mathrm{O}$ per acre, plus a very high $\mathrm{CaCO}_{a}$ content, no significant amounts of sulphates or chlorides, a $\mathrm{pH}$ of 8.0 , conductivity of 0.4 and a medium-high organic matter level. The high lime content in relation to the deficient phosphorus content suggests definite phosphorus deficiencies in plants and animals utilizing the area. One case of aphosphorosis in deer was observed.

Strip cutting in a staggered design with the strip lengths at right angles to the westerly prevailing winds was used in harvesting the spruce forest in the study area. The cut over strips were 5 and 10 chains wide and 40 to 48 chains long. Five chain width residual strips were left between the logged over strips. The residual strips are to be cut $12-15$ years following the commencement of logging, so that the entire area will be logged in 25 years. This logging practice is part of a large over-all logging program for the entire 3,000 square mile lease area based on a 100-year rotation. The four working circles which contain five cutting compartments are logged off in sequence beginning with the most mature stands so that at the end of the first 100-year rotation, five broad age classes of timber will exist-viz. 0-20, 20-40, 40-60, 60-80, 80-100 years. The pulp company is committed to a sustained yield program whereby if 350 thousand cords of pulpwood bolts are harvested annually, then a similar increment must occur in the remaining forest stand. For further details consult Clark (1960).

The big game range study was initiated in 1957 . In the spring of 1959 , the detailed white spruce study was established. During the summer of 1959, permanent range plots were established in the three forest types. Range data 
were gathered from the permanent white spruce plots in the three-year-old scarified and unscarified logged over strips. To gather corresponding data from logged over strips one and two years old, strips within one-half mile of the permanent three-year-old plots were used. This may explain some of the dis-

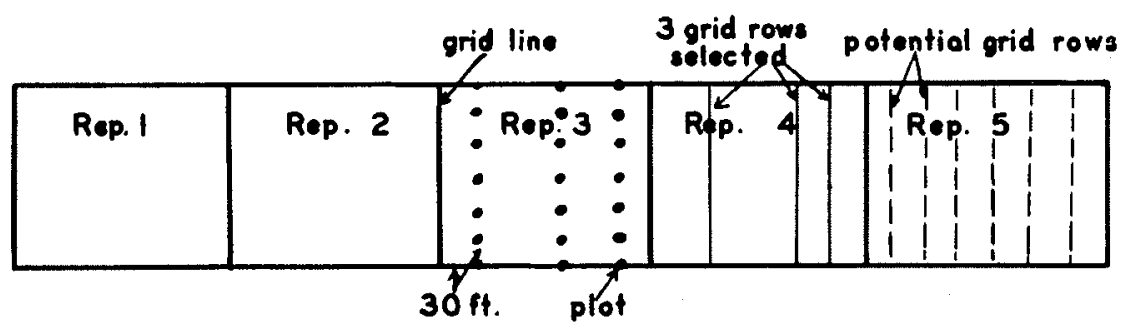

FIGURE 1, Diagrammatic Sketch of Sampling Design.

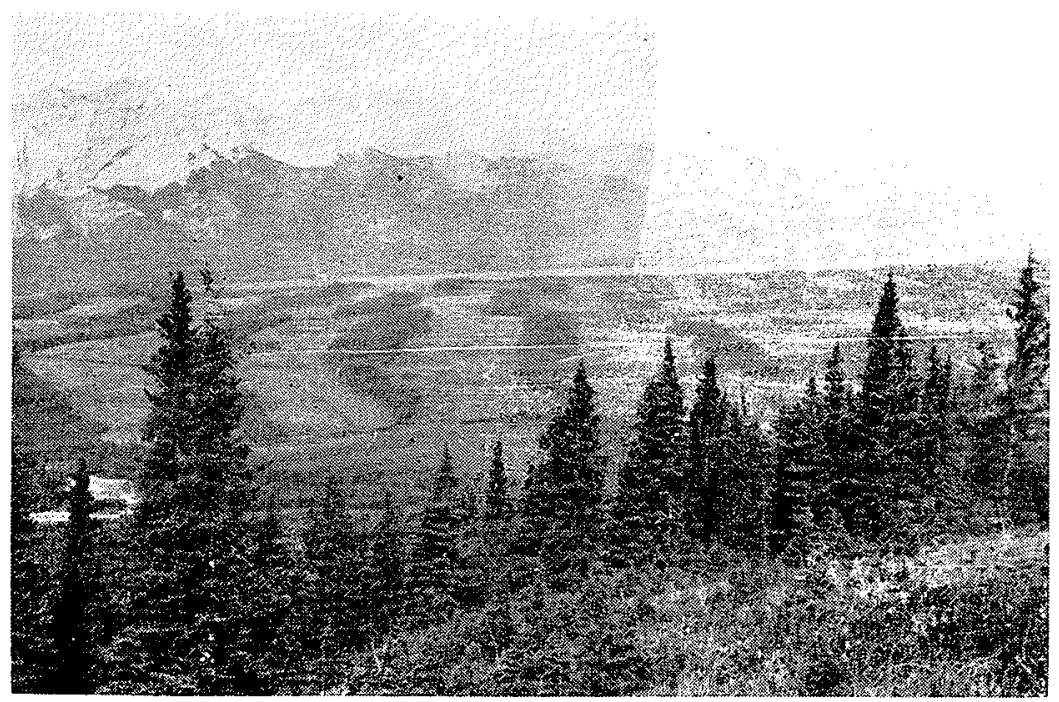

FIGURE 2. $\Lambda$ view of the study area showing five year old logged over strips. 


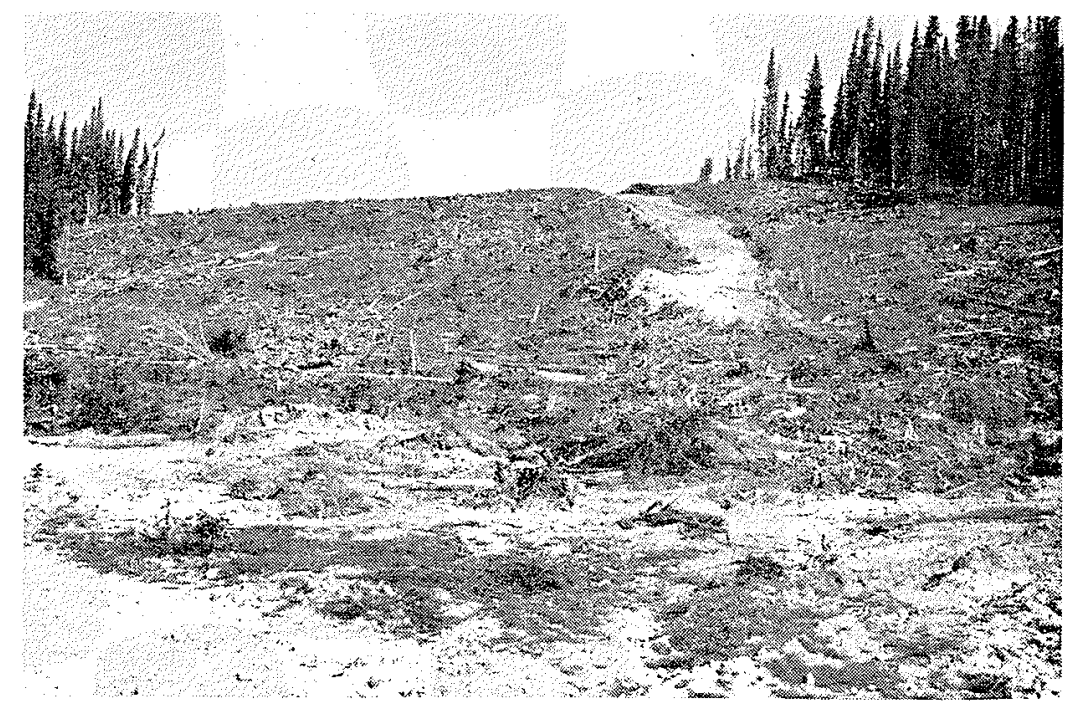

FIGURE 3. Recently logged and scarified strip in white spruce forest.

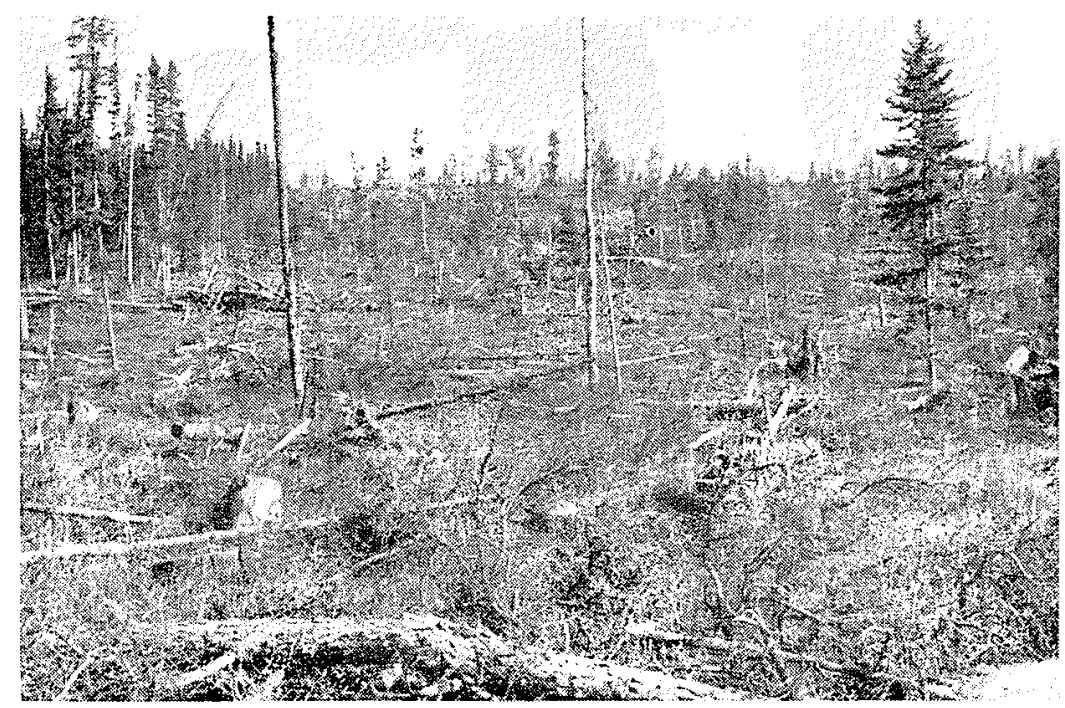

FIGURE 4. Recently logged over but unscarified strip in white spruce forest. 


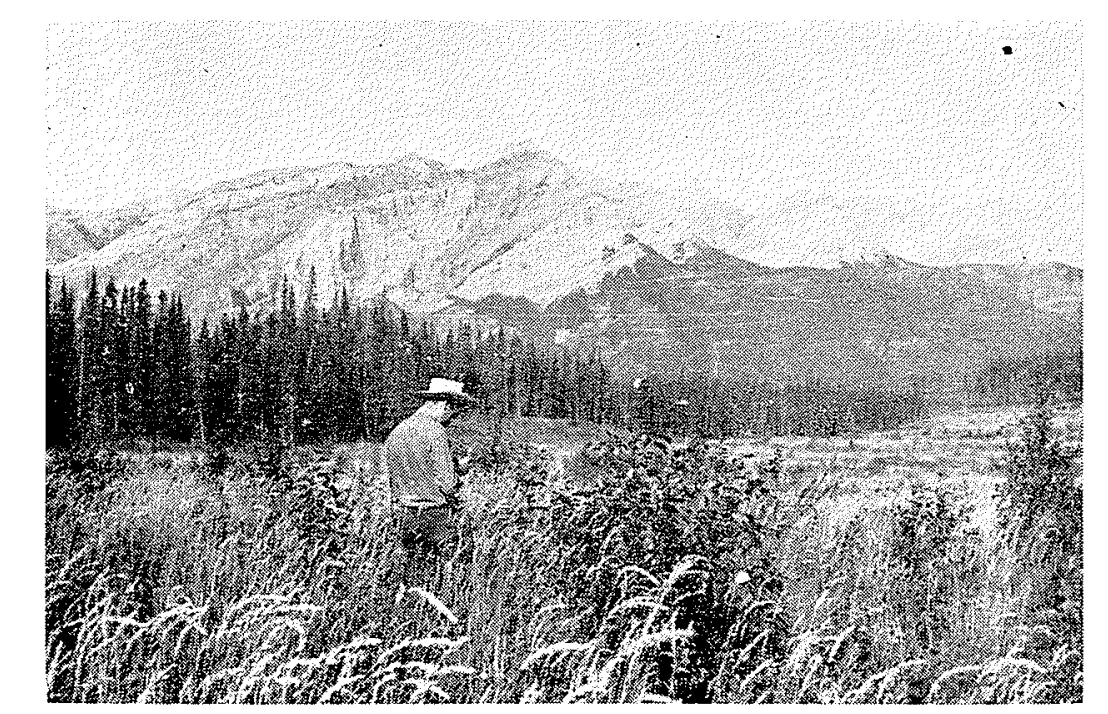

FIGURE 5. 5 year old logged and scarified strip. Note height of poplar and willow, also dense hairy wild rye growth.

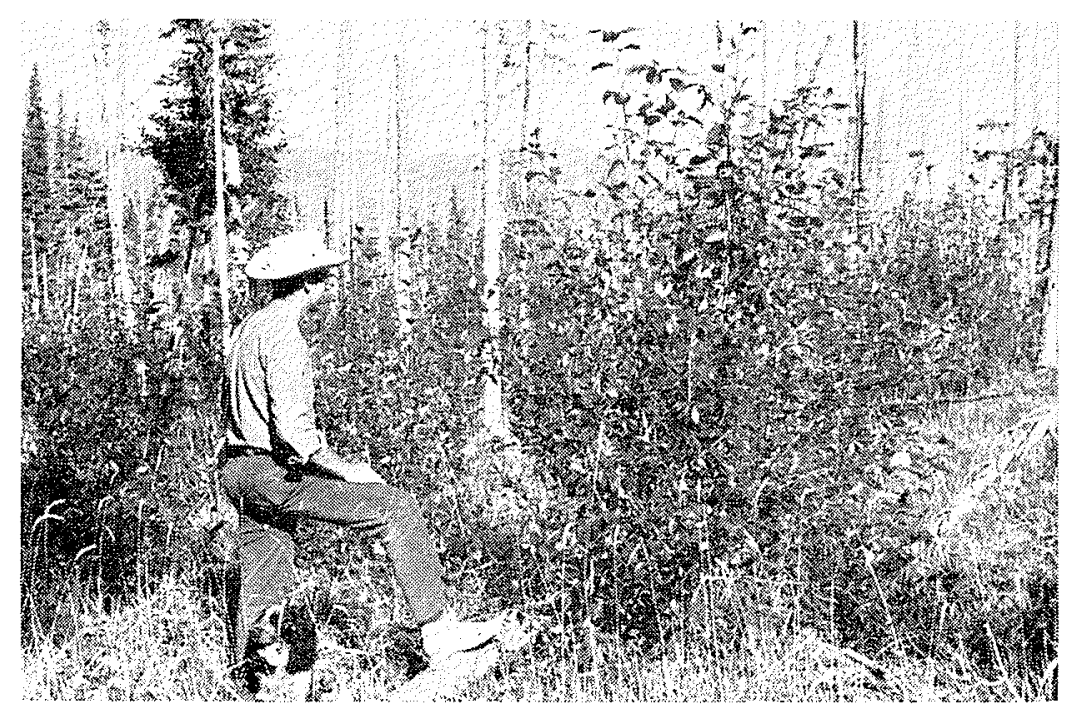

FIGURE 6. 5 year old logged and unsearified strip. Note height of poplar and willow compared to Figure 4. 
TABLE 1

Average Monthly Winter Snowfall (1955 Through 1960)

\begin{tabular}{lclc}
\hline \multicolumn{1}{c}{ Month } & $\begin{array}{c}\text { Inches } \\
\text { Snowfall }\end{array}$ & Month & $\begin{array}{c}\text { Inches } \\
\text { Snowfall }\end{array}$ \\
\hline October & 8.95 & February & 9.60 \\
November & 5.25 & March & 7.00 \\
December & 12.75 & April & 7.50 \\
January & 11.20 & May & 1.97 \\
\hline
\end{tabular}

TABLE 2

Average Mean Monthly Temperature Readings For the Three Year Period 1957-1960 at Hinton

\begin{tabular}{lllllr}
\hline Month & $\begin{array}{c}\text { Average } \\
\text { Tempera- } \\
\text { ture }{ }^{\circ} \mathbf{F}\end{array}$ & Month & $\begin{array}{c}\text { Average } \\
\text { Tempera- } \\
\text { ture }{ }^{\circ} \mathbf{F}\end{array}$ & Month & $\begin{array}{r}\text { Average } \\
\text { Tempera- } \\
\text { ture }{ }^{\circ} \mathbf{F}\end{array}$ \\
\hline January & 12.35 & May & 50.00 & September & 50.47 \\
February & 19.98 & June & 57.25 & October & 38.82 \\
March & 28.97 & July & 62.62 & November & 24.77 \\
April & 39.83 & August & 57.00 & December & 26.97 \\
\hline
\end{tabular}

crepancies in range trend seen in the tables. Range information for years three, four and five were from the same plots except for the weight and utilization information, where clipping was taken a specified distance from the permanent plots. One big game exclosure plot (50 ft. x $50 \mathrm{ft}$.) was established in 1960 in each of the three forest types on the 1956-57 cut and scarified strips.

The range information was gathered from six permanent sample areas established as follows: two in the mature white spruce forest, two in the logged over strips, and two in the scarified logged over strips. Each sampling area consisted of five replications, each containing six potential grid rows (from which three rows were selected at random) plus the grid line. Each of the 15 selected grid rows per sample contained seven sampling plots $(9.6$ square feet) spaced 30 feet apart. Each of the two samples encompassed an area 180 feet by 1050 feet. A total of 210 plots were taken for each area studied. Figure 1 illustrates the sampling technique employed. The 9.6 square foot plot sampler was left open on one side, to facilitate placing the plot sampler in brushy vegetation. Big game species abundance and distribution were calculated from visual observations, pellet counts, winter aerial surveys, residual strip beat-outs, and track counts involving the use of a road drag. Plant coverage information refers to the amount of ground shaded by each plant species.

Forage weight and utilization data were gathered by weighing the green palatable forage on a gram scale. Where part of the forage was utilized, the total forage weight was obtained by adding to the amount weighed and estimate of the weight of forage consumed.

The first half of August proved to be the most suitable time phenologically and climatologically to gather range data from this area. Late August rains 
and possible early September snows coupled with normal desiccation of herbaceous vegetation and leaf fall in early September precluded any hope of accurately gathering range data after August 15 th.

\section{RESULTS AND DISCUSSION}

\section{Species Composition and Coverage}

Canopy (ground) coverage is presented in Table 3 for the important browse, grass and forb species in the uncut white spruce forest and for the first five years following logging.

The general browse canopy picture in the fifth year revealed that the coverage in the mature forest was still twice that in the scarified strips and one-quarter more than that in the unscarified strips. Despite this greater browse coverage in the mature forest, the weight of usable browse and the actual utilization of the available browse was substantially greater in the logged areas, as revealed in Table 4. Presumably there is a higher proportion of palatable forage in the new succulent growth of the logged areas than in the older browse of the mature forest. In studying the effects of heavy selection logging on herbaceous vegetation in a ponderosa pine forest in northern Arizona, Arnold (1953) found that heavy selection logging had very little effect on herbaceous plant density five years after logging. However in his study the canopy was decreased only 25.4 per cent compared to complete tree canopy removal in this study in the scarified sites and roughly 75 per cent removal in the unscarified logged over strips.

Willows comprised over 41 per cent of the browse canopy coverage in the mature forest, followed by rose (Rosa spp.) with 35 per cent, and junipers (Juniperus communis and $J$. horizontalis) 18 per cent. Five years following logging, rose had regained the canopy coverage, in both logged types, that it had prior to logging. Willow had only regained one-half of its pre-logged coverage in the unscarified strips and about one-eighth its pre-logged coverage in the scarified strips. On the other hand, poplar (Populus balsamifera and $P$. tremuloides) increased steadily following logging until in the 5 th year it covered 41 times as much area in the unscarified strips, and 18 times as much area in the scarified strips, as in the mature forest. The other browse species changed little or increased slowly except for the junipers, raspberries (Rubus spp.) and buffaloberry (Shepherdia canadensis) which decreased in canopy coverage.

During the first year, grass cover was reduced one-third of its former cover by logging, and was reduced two-thirds by both logging and scarification. In a study on the Burgess Spring Experimental Range in north eastern California, Hormay (1940) found that logging by tractors and arches reduced the grazable forage on the ground by about 19 percent at the time of logging. At Hinton, grass encroached quickly on the cut-over strips until it covered approximately 50 percent of the ground in the 5 th year in both the scarified and unscarified areas. Arnold (1953) found that grass density decreased 40 percent in the fifth year following logging (that reduced the canopy 25.4 percent) from that present in the mature stand. In the Hinton study, hairy wild rye (Elymus innovatus) comprised 90 percent of the grass cover in the scarified 
TABLE 3

Canopy Coverage (Percentage of Ground Coverage)

Number of Growing Seasons following Logging

\begin{tabular}{|c|c|c|c|c|c|c|c|c|c|c|c|}
\hline \multirow{3}{*}{$\begin{array}{l}\text { Plant } \\
\text { Species }\end{array}$} & \multirow{3}{*}{$\begin{array}{l}\text { Mature } \\
\text { Forest }\end{array}$} & \multirow{2}{*}{\multicolumn{10}{|c|}{ Number of Growing Scasons Following Logging }} \\
\hline & & \multicolumn{2}{|c|}{1} & \multicolumn{2}{|c|}{2} & \multicolumn{2}{|c|}{3} & 4 & & & 5 \\
\hline & & Scar. ${ }^{2}$ & Unsc. ${ }^{2}$ & Sear. & Unscar. & Sear. & Unscar. & Scar. & Unscar. & Scar. & Unscar. \\
\hline \multicolumn{12}{|c|}{ BROWSE } \\
\hline Juniperus & 3.22 & .11 & .45 & .04 & .81 & .27 & .52 & .04 & .19 & .04 & .50 \\
\hline Lonicera & .13 & .02 & .13 & .02 & .24 & .07 & .06 & .01 & .21 & .03 & .44 \\
\hline Populus & .07 & .05 & .22 & .35 & .28 & 1.10 & 2.34 & .34 & 2.32 & 1.29 & 2.94 \\
\hline Rosa & 5.97 & .96 & 2.40 & 1.50 & 4.80 & 5.00 & 5.70 & 3.52 & 4.63 & 5.23 & 5.62 \\
\hline Salix & 7.20 & .90 & 1.13 & 2.26 & 1.20 & 3.47 & 1.33 & .40 & 2.03 & .94 & 3.79 \\
\hline Shepherdia & .10 & .06 & .40 & .07 & .53 & .02 & .02 & .02 & .07 & .07 & .07 \\
\hline Viburnum & .07 & .01 & .04 & .01 & .07 & .01 & .10 & .02 & .01 & .03 & .01 \\
\hline Others & .60 & .01 & .15 & .02 & .14 & .39 & .20 & .17 & .05 & .25 & .37 \\
\hline \multirow{2}{*}{ Totals } & $\overline{17.36}$ & 2.12 & 4.92 & 4.27 & 8.07 & 10.33 & 10.27 & 4.52 & 9.51 & 7.88 & 13.74 \\
\hline & & & GRA & S AND & GRASS & LIKE & PLANTS & & & & \\
\hline Bromus & .07 & - & .03 & .60 & .77 & .10 & .02 & .08 & .09 & .04 & .18 \\
\hline Calamagrostis & - & - & .01 & .19 & .12 & .50 & .22 & .02 & .50 & .03 & 1.41 \\
\hline \multicolumn{12}{|c|}{ Carex \& Glyceria } \\
\hline striata & 21.81 & 1.87 & 6.70 & 5.75 & 9.86 & 4.85 & 10.62 & 2.29 & 6.09 & 3.99 & 11.70 \\
\hline Elymus & 6.43 & 7.73 & 11.33 & 12.00 & 18.39 & 15.71 & 23.71 & 26.78 & 22.45 & 45.10 & 37.40 \\
\hline Others & .27 & - & .06 & .19 & .38 & .08 & .97 & .03 & .69 & .11 & .27 \\
\hline \multirow[t]{2}{*}{ Totals } & 28.58 & 9.60 & 18.13 & 18.73 & 29.52 & 21.24 & 35.54 & 29.10 & 29.82 & 49.27 & 50.96 \\
\hline & \multicolumn{11}{|c|}{ FORBS } \\
\hline Aster & .27 & .06 & .30 & .18 & 1.20 & 1.20 & .94 & .49 & .95 & 1.43 & 1.40 \\
\hline Hedysarum & .98 & .42 & .74 & .01 & 1.03 & .19 & .90 & .31 & 1.35 & .67 & 2.34 \\
\hline Mertensa & .24 & .14 & .33 & .16 & .40 & .65 & .80 & .52 & .30 & .54 & .45 \\
\hline Senecio & .01 & - & .01 & .05 & .08 & .30 & .09 & .33 & .76 & .79 & .83 \\
\hline Zigadenus & - & .01 & .08 & .08 & .12 & .13 & .23 & .16 & .20 & .11 & .09 \\
\hline Others & .14 & .03 & .35 & .05 & 1.06 & .78 & .39 & .42 & .68 & 1.05 & 1.06 \\
\hline Totals & 1.64 & .66 & 1.81 & .53 & 3.89 & 3.25 & 3.35 & 2.23 & 4.24 & 4.59 & 6.17 \\
\hline
\end{tabular}

1Scarified by a D-9 "Cat" following logging

2 Unscarified 
areas and 73 percent of the grass cover in the unscarified areas. Utilization of this grass by big game was negligible during the summer and winter in this area, though the new shoots in the spring were readily eaten. The dense grass coverage appeared to impede coniferous seed germination and survival. Avena fatua, Avena sativa, and Phleum pratense showed up in the logged plots but not in the mature spruce plots. This is probably accounted for by the use of skid horses during logging operations. Poa and Festuca species increased in ground cover following logging.

Forb coverage tripled five years after logging and scarification, and increased four-fold in unscarified strips, over that present in the uncut spruce. Similar results are shown in a logged over Ponderosa pine forest five years after logging (Arnold, 1953). Deer and elk used these forbs as their chief summer food in the cut-over strips. Aster spp., Hedysarum spp., Senecio spp., Erigeron spp., Epilobium spp., Mertensia paniculata and Zigadenus elegans comprised the bulk of the forb coverage and all were readily utilized by deer and elk. Twenty-six species of forbs appeared in the logged over plots that were not found in the mature spruce plots. Ten of these species (mainly the ones listed above) were fairly common in the logged plots.

\section{Forage Weight and Utilization}

Table 4 shows the changes that occurred in browse weight and utilization between the mature spruce forest and the five years following logging. This table does not include data on junipers and bearberry (Arctostaphylos uvaursi) as these shrubs were not utilized. Three years following logging the unscarified strips produced as much edible browse as that in the mature forest, whereas it required between four and five years for the scarified strips to attain the same production. The gaps in utilization in Table 4 reveal inadequate sampling. Ocular observations revealed utilization, but it was patchy and failed to show up on the 44 clip plots utilized in each experimental type.

Five years following logging, the scarified areas yielded nearly 50 percent more usable browse, and the unscarified 70 percent more usable browse, by weight than in the uncut forest. Studies in northern Michigan have also shown the increased deer forage production that arises in the early years following logging (Gysel, 1957).

Almost twice the weight of browse was utilized in the five-year-old unscarified strips, and 1.6 times the weight in the same age scarified strips, as in the mature spruce. Greatest utilization occurred during the third year following logging. During the fourth and fifth years big game populations were less following a liberal big game either-sex hunting season during the falls of the third and fourth years.

Deer utilized the unscarified strips more than twice as much as the scarified strips until the third year after logging, following which this difference lessened. Deer were not frightened out of the areas being logged, as were the elk and moose, but utilized the cut-over areas almost entirely as summer range for the first five post-logging years.

Elk utilized only the periphery of the logged-over region during the first three years, but ranged more extensively over the logged areas during the fourth and fifth years. 
TABLE 4

Usable Browse Weioht and Utilization (Pounds PER ACre)

\begin{tabular}{|c|c|c|c|c|c|c|c|c|c|c|c|c|}
\hline \multirow[b]{2}{*}{$\begin{array}{c}\text { Plant } \\
\text { Species }\end{array}$} & & \multirow[b]{2}{*}{$\begin{array}{l}\text { Mature } \\
\text { Forest }\end{array}$} & \multicolumn{10}{|c|}{ Years Following Logging } \\
\hline & & & Scar. & 1 & Scar. & 2 & \multicolumn{2}{|c|}{3} & \multicolumn{2}{|c|}{4} & \multicolumn{2}{|c|}{5} \\
\hline \multirow{2}{*}{$\begin{array}{l}\text { Populus } \\
\text { spp. }\end{array}$} & Wt. & 20.7 & 11.3 & 16.8 & 12.0 & 226.1 & 37.0 & 46.3 & 103.7 & 115.5 & 454.5 & 259.7 \\
\hline & Util. & 2.7 & - & - & - & 15.9 & - & - & - & 1.6 & - & 0.6 \\
\hline \multirow{2}{*}{$\begin{array}{l}\text { Rosa }_{\text {spp. }} \\
\text {. }\end{array}$} & Wt. & 144.4 & 49.5 & 97.4 & 122.6 & 152.5 & 115.3 & 305.5 & 252.4 & 286.0 & 270.1 & 238.8 \\
\hline & Util. & 9.5 & 2.0 & 12.5 & 8.6 & 19.1 & 29.1 & 83.3 & 11.1 & 2.3 & 20.0 & 6.5 \\
\hline \multirow{2}{*}{$\begin{array}{l}\text { Salix } \\
\text { spp. }\end{array}$} & Wt. & 323.3 & 39.3 & 53.3 & 99.4 & 22.9 & 53.6 & 156.6 & 60.4 & 227.4 & 11.3 & 341.9 \\
\hline & Util. & - & - & 3.2 & - & 4.4 & 1.4 & - & 1.4 & 1.1 & - & 13.6 \\
\hline \multirow{2}{*}{$\begin{array}{l}\text { Shepherdia } \\
\text { canadensis }\end{array}$} & Wt. & 28.1 & .7 & 1.8 & - & 5.0 & 6.1 & 22.7 & 2.9 & 11.6 & 7.7 & 13.3 \\
\hline & Util. & 0.5 & - & .3 & - & - & - & - & 一 & - & - & 一 \\
\hline \multirow[t]{2}{*}{ Others } & Wt. & 12.3 & .3 & 17.9 & 12.0 & 14.8 & - & 20.7 & 18.6 & 31.8 & 62.2 & 35.8 \\
\hline & Util. & 1.8 & - & - & 1.8 & 2.3 & - & 6.1 & - & - & 4.1 & 5.7 \\
\hline \multicolumn{2}{|l|}{ Total Weight } & 528.8 & 101.1 & 187.2 & 246.0 & 421.3 & 212.0 & 551.8 & 438.0 & 672.3 & 805.8 & 889.5 \\
\hline \multicolumn{2}{|c|}{ Total Utilization } & 14.5 & 2.0 & 16.0 & 10.4 & 41.7 & 30.5 & 89.4 & 12.5 & 5.1 & 24.1 & 26.4 \\
\hline
\end{tabular}


Moose used the cut-over strips only as travel lanes during the first five successional years.

\section{Shrubs and Tree Heights}

In general, browse heights had returned to their pre-logged heights by the fifth successional year. In the unscarified plots, at this time, willow and poplar heights were one-third higher, and rose heights one-fifth higher than those in the mature spruce. In the scarified plots, in the fifth successional year, willow and poplar heights were one-fifth and one-third less respectively than their pre-logged heights while rose was over one-quarter higher. Figures 5 and 6 show the variations in willow and poplar heights between the scarified and unscarified strips five years following logging. Willow heights in the scarified strips appear to be about a year behind heights in the unscarified strips. Correspondingly, poplar heights appeared to lag about two years compared to heights in the unscarified strips.

\section{Big Game Populations}

Following logging of approximately one square mile of white spruce in 1956 , the deer population increased noticeably by the summer of 1959 . Summer deer observations indicated six to eight mule deer and two white-tailed deer utilizing the three-year-old regrowth extensively. Twelve to fifteen elk used only the periphery of the area during the first three years and three to four moose wandered occasionally through the area. The deer seemed to be drawn in from the adjacent mature spruce forests where summer deer populations were observed to be much less. At this time observations made in nearby one- and two-year-old cut-over areas revealed a lower deer density than in the three-year-old regrowth areas.

Big game plant utilization and pellet count studies of adjacent one-, twoand three-year-old regrowth areas and in nearby mature stands taken during the summer of 1959 confirmed the greater deer use in the three-year-old strips compared to the one- and two-year-old strips and the mature spruce. The deer used the two-year-old regrowth strips much more than the one-year-old strips. Deer numbers in the fourth and fifth years dropped appreciably from the third year. This may have been the result of long either-sex hunting season during the previous fall or the fact that the deer were drawn to the nearby more recently cut strips. Three or four moose still wandered occasionally through the strips while the $12-15$ elk increased their summer use to cover 50 to 75 percent of the logged over area.

Winter big game counts involving complete "beat-outs", aerial counts with a helicopter, plus track counts revealed that, during the first four winters following logging, deer, moose and elk used the area very little.

\section{General Discussion}

This study indicates that clear cut logging of mature white spruce in western Alberta will result in greater big game forage production during the first five years of forest regeneration. Though significant changes in moose, deer and elk numbers cannot be expected during the first five succession years, greater big game harvests can be attained due to the increased hunter access 
provided by logging roads and increased visibility due to the reduced canopy coverage. Hundreds of square miles of big game range in western Alberta have become accessible to hunters during the past five years due to pulp logging activities. The immediate benefits of logging large stands of virgin timber in Alberta are therefore not the increases in big game numbers, but the ability to harvest an existing renewable game resource previously inaccessible. Immediate increase in the carrying capacity of summer deer and elk range occurs through an increase in the forb and grass cover and in the greatest number of species present.

The five broad forest age classes resulting from the sustained yield silvicultural practices in effect over this 3,000 square mile tract of big game range should result in a sustained yield of moose, deer and elk numbers. Caribou populations are expected to dwindle substantially once their range has been logged over except possibly for some large muskeg areas where the harvesting of black spruce is impractical.

Pellet group counts proved to be ineffectual as a measure of big game use due to the difficulty of detecting pellets that had fallen through the spruce slashing and because of the dense grass coverage. Pellet counts served some purpose in showing relative game use by different big game species and game use between different logged over strips.

Scarification of logged over spruce areas could conceivably shorten the brush seral stages compared to the unscarified areas, and thus reduce the productive big game period during coniferous regeneration. However, this depends on the rapidity with which coniferous seedlings become established, which also depends directly on the availability of coniferous seed at the time of scarification. In the area under study a good white spruce seed crop did not occur until the third year following logging and by this time the grass cover was so dense that much of the benefits of scarification may have been lost. In this case the interval between logging and coniferous forest re-establishment may be similar for the scarified and unscarified areas.

\section{SUMMARY}

Scarification following logging retarded big game forage production and utilization one to two years compared to the unscarified logged areas. Usable browse production dropped from 529 pounds per acre under the mature spruce forest to 101 pounds per acre following logging and scarification and to 187 following logging with no scarification.

Although browse coverage was greater in the mature forest than in the logged areas five years following logging, the weight of usable browse, and the actual summer utilization of the available browse were substantially greater in the logged areas.

Grass encroached quickly on the cut-over strips until it covered approximately 50 percent of the ground in the fifth year in both the scarified and unscarified areas. This dense grass coverage appeared to impede coniferous seed germination and survival. 
Forb coverage tripled in the scarified strips and quadrupled in the unscarified strips in the fifth year after logging, compared to that present in the uncut spruce.

Big game use of the logged over areas was almost entirely summer use during the first five years. Deer used the entire logged over area while elk confined their feeding activities to the periphery of the area until the fourth and fifth year when they foraged more widely over the area. Moose ignored the logged over areas, except as travel lanes during the first five years following logging. Although no significant changes in big game numbers and range utilization occurred during the first five years following logging, important benefits did result. Due to the development of new logging roads, hundreds of square miles of good moose, deer and elk country became accessible to the hunters and the wildlife resource previously largely wasted was cropped.

\section{ACKNOWLEDGEMENTS}

The author wishes to express his gratitude to the following persons and organizations who helped to make this study possible: Drs. L. A. Stoddart, J. B. Low, J. L. Mielke, and A. D. Smith (Utah State University) who guided him in setting up the study. Drs. E. H. Moss, R. G. H. Cormack, and J. Packer (Department of Botany, University of Alberta) for identifying the plant species found in the study area. Alberta Department of Lands and Forests for giving the author the time required to carry out the study. Northwestern Pulp and Power Company at Hinton for its generous co-operation.

Mr. G. R. Kerr (Asst. biologist), Alberta Fish and Wildlife Division, for diligent assistance in gathering field data for two summers.

\section{REFERENCES}

ARNOLD, JOSEPH F, 1953. Effect of heavy selection logging on the herbaceous vegetation in a ponderosa pine forest in northern Arizona. J. For. 51 (2): 101-105.

CLARK, J. D. 1960. Cutting practices in western spruce forests. For. Chron. 36 (2): 146-149. CORMACK, R. G. H. 1953. A survey of coniferous forest succession in the eastern Rockies. For. Chron. 29 (3): 218-232.

GYSEL, LESLIE W. 1957. Effects of silvicultural practices on wildlife food and cover in oak and aspen types in northern Michigan. J. For. 55: 803-809.

HORMAY, A. L. 1940. The effect of logging on forage. Chronica Botanica 6 (1): 6-7. MOSS, E. H. 1953. Forest communities in northwestern Alberta. Can. J. Bat. 31 (2): 212-252. 